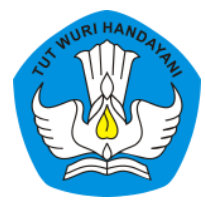

Page: 637-656

\title{
PENINGKATAN KEMAMPUAN BERPIKIR KRITIS DAN HASIL BELAJAR PESERTA DIDIK MELALUI MODEL PEMBELAJARAN DISCOVERY LEARNING
}

\author{
Siti Luthfah Ridwan \\ Sekolah Menengah Pertama Negeri 1 Tilamuta, Boalemo, Gorontalo, Indonesia \\ Contributor Email: sitiluthfahridwan@gmail.com
}

Received: Jan 18, 2021

Accepted: Jul 2, 2021

Published: Nov 30, 2021

Article Url: https://ojsdikdas.kemdikbud.go.id/index.php/didaktika/article/view/201

\begin{abstract}
Meaningful learning is learning that takes the side of students and makes students as the main actors who are active with their friends identifying problems, looking for solutions and concluding and actively communicating in learning activities. Activities like this can be done by implementing the Discovery Learning model. The purpose of this study was to improve critical thinking skills and student learning outcomes in the classification of living things. This research is a Classroom Action Research model of Kemmis and Taggart through four stages, namely planning, implementing, observing, and reflecting which were carried out in two cycles and each cycle carried out three meetings. The results of the data analysis showed that the percentage of students who achieved the critical thinking indicator was 14 students (56.00\%), 17 students (68.00\%) who achieved the knowledge competency learning outcomes. Whereas in Cycle 2, there were 22 students $(88.00 \%)$ who reached the critical thinking ability indicator, and 21 students (84.00\%) who reached the learning outcome indicator. From the results of these studies it can be concluded that the Discovery Learning learning model can improve critical thinking skills and learning outcomes of students.
\end{abstract}

Keywords: Critical Thinking; Learning Outcomes; Discovery Learning. 


\begin{abstract}
Abstrak
Pembelajaran bermakna adalah pembelajaran yang berpihak kepada peserta didik dan menjadikan peserta didik sebagai pelaku utama yang aktif bersama temannya mengidentifikasi masalah, mencari solusi dan menyimpulkan serta mengomunikasikan secara aktif dalam kegiatan pembelajaran. Kegiatan seperti ini dapat dilakukan dengan mengimplementasikan model Discovery Learning. Tujuan penelitian ini adalah untuk meningkatkan kemampuan berpikir kritis dan hasil belajar peserta didik pada materi klasifikasi mahkluk hidup. Penelitian ini merupakan Penelitian Tindakan Kelas model Kemmis dan Taggart melalui empat tahapan yakni perencanaan, pelaksanaan, pengamatan, dan refleksi yang dilaksanakan sebanyak dua siklus dan masing-masing siklus dilaksanakan sebanyak tiga kali pertemuan. Hasil analisis data menunjukkan persentase jumlah peserta didik yang dapat mencapai indikator berpikir kritis berjumlah 14 orang siswa $(56,00 \%)$, peserta didik yang mencapai hasil belajar kompetensi pengetahuan 17 orang siswa (68,00\%). Pada Siklus 2, peserta didik yang mencapai indikator kemampuan berpikir kritis berjumlah 22 orang (88,00\%), dan 21 orang $(84,00 \%)$ yang mencapai indikator hasil belajar. Dari hasil penelitian dapat disimpulkan bahwa model pembelajaran Discovery Learning dapat meningkatkan kemampuan berpikir kritis dan hasil belajar peserta didik.
\end{abstract}

Kata Kunci: Berpikir Kritis; Hasil Belajar; Discovery Learning.

\title{
A. Pendahuluan
}

Peserta didik dalam kehidupannya sering diperhadapkan dengan berbagai macam masalah, dan sebagian dari mereka masih kesulitan dalam mencari solusi pemecahannya dan bahkan memilih berputus asa. Hal tersebut bisa terjadi karena mereka belum memiliki kemampuan bagaimana cara menyelesaikan masalahnya dengan menggunakan kemampuan berpikirnya. Salah satu kemampuan berpikir yang sebaiknya dimiliki oleh setiap individu adalah kemampuan berpikir kritis. Salah satu cara untuk menumbuhkan kemampuan berpikir kritis mereka tentu saja melalui bangku pendidikan yakni dari proses pembelajaran. Proses pembelajaran merupakan aktivitas yang dilakukan oleh guru dan peserta didik dengan tujuan dapat mengubah keadaan dari yang belum baik menjadi lebih baik., dari belum tahu menjadi tahu, dari belum mampu menjadi mampu melalui interaksi aktif untuk mencapai tujuan pembelajaran. Tujuan pembelajaran yang dimaksud salah satunya adalah kemampuan berpikir kritis dan hasil belajar ranah kognitif. 
Berhasil tidaknya peserta didik mengembangkan kompetensi belajarnya tergantung pada mampu tidaknya seorang guru dalam mendesain, merencanakan dan mengelola proses pembelajaran. Idealnya dalam kegiatan pembelajaran peserta didik bertindak sebagai pelaku, sebagai penemu, sebagai peneliti dan semua kegiatan yang dilakukan merupakan pengalaman baru yang dilatih dan dikembangkan oleh guru. Semua kemampuan itu dapat dilatih melalui pembelajaran kontekstual. Kadir (2013: 36) menyatakan bahwa pembelajaran kontekstual merupakan salah satu alternatif pembelajaran yang dilakukan untuk mengurangi cara belajar secara verbal yang hanya terfokus pada penguasaan materi, tetapi cara belajar yang dapat menguatkan pemahaman secara menyeluruh melalui pengalaman langsung yang sering ditemui di dunia nyata. Hal ini menunjukkan bahwa pembelajaran kontekstual dapat memberikan pengalaman belajar yang lebih bermakna sehingga pengalaman belajar yang di dapat dari dalam kelas dapat dibawa keluar kelas untuk diaplikasikan ke dunia nyata, sebagaimana pernyataan yang dikemukakan oleh Abdullah, A. A \& Richardo, R. (2017: 93), melalui pembelajaran kontekstual pengalaman belajar bukan hanya terjadi dan dimiliki seseorang ketika berada di dalam kelas, tetapi jauh lebih penting dari itu namun dapat membawa pengalaman belajarnya sampai keluar kelas, yakni pada saat dituntut untuk menanggapi dan memecahkan permasalahan yang nyata yang akan dihadapi dalam kehidupan sehari-hari.

Salah satu model pembelajaran kontekstual yang dapat aplikasikan adalah model pembelajaran kooperatif tipe Discovery Learning atau model pembelajaran penemuan. Kegiatan pembelajaran penemuan (Discovery Learning) dapat dirancang oleh guru untuk memperbaiki proses pembelajaran, karena jika kegiatan pembelajaran yang dirancang oleh guru kurang baik maka akanberpengaruh pada perolehan hasil belajar yang kurang baik pula. Guru dituntut mampu membuat peserta didik dapat melakukan eksplorasi, penemuan-penemuan baru yang belum dikenal atau pengertian yang mirip dengan yang sudah diketahui sebelumnya, sesuai dengan salah satu prinsip Kurikulum 2013 yang menekankan pada dimensi pedagogik modern dalam pembelajaran. Dimensi ini menggunakan pendekatan ilmiah (scientific appoach) yang di dalamnya menuntut kemampuan peserta didik menggali informasi 
melalui pengamatan, bertanya, melakukan percobaan, kemudian mengolah data atau informasi, menyajikan data atau informasi, dilanjutkan dengan menganalisis, menalar, kemudian menyimpulkan, dan mencipta, sehingga peserta didik dapat mencapai kompetensi tertentu dan bersifat multidimensi yang seimbang antara keterampilan fisikal (hardskills) dan keterampilan mental (softskills).

Dalam kegiatan pembelajaran, siapa saja adalah guru; siapa saja adalah siswa; dan di mana saja adalah ruang kelas. Jika hal ini dilaksanakan secara optimal, tujuan pembelajaran yang orientasinya adalah pengembangan kompetensi sikap, pengetahuan, dan keterampilan bisa berhasil. Namun kenyataannya, pembelajaran yang dirancang oleh guru masih menjadikan peserta didikcenderung pasif dan belum menunjukkan motivasi yang baik dalam kegiatan pembelajaran serta hanya sebagai obyek yang siap mendengar, menyimak, dan akhirnya merekamerasa ngantuk dan bosan di kelas. Kenapa hal ini dapat terjadi? Tentu saja karena pembelajaran yang dilakukan oleh guru masih konvensional dan membatasi aktivitas peserta didik. Interaksi antara satu peserta didik dengan peserta didik lainnya belum memberikan pengalaman belajar. Pembelajaran hanya berupa kegiatan yang monoton setiap hari dan begitu-begitu saja sehingga membuat peserta didik jenuh dan guru merasa sangat kelelahan. Guru sekadar mengajar seperti biasanya, hanya menggugurkan kewajiban berdiri di dalam kelas dengan cara menjelaskan kemudian memberikan tugas untuk dibahas baik secara mandiri atau berkelompok namun belum menekankan pada tahapan-tahapan pembelajaran kontekstual yang dapat mengembangkan potensi peserta didik secara maksimal. Padahal, menurut (Nur, 2011: 17), dalam kegiatan belajar mengajar mengandung kegiatan interaksi antara guru dan peserta didik dan komunikasi timbal balik yang berlangsung dalam situasi edukatif untuk mencapai tujuan belajar. Untuk memperbaiki kondisi tersebut di atas, maka perlu dilakukan usaha perbaikan, misalnya dengan menerapkan model pembelajaran yang dapat membantu peserta didik sebagai pelaku yang aktif, mandiri serta dapat melakukan berbagai macam kegiatan belajar yang bermakna. Salah satu diantaranya adalah dengan menerapkan model pembelajaram penemuan (Discovery Learning). 
Menurut teori kontruktivisme agar peserta didik benar-benar memahami dan mampu menerapkan pengetahuan, mereka harus bekerja memecahkan masalah, menemukan segala sesuatu untuk untuk dirinya, berusaha dengan susah payah dengan ide-ide (Trianto, 2007: 24). Hal ini menunjukkan bahwa peserta didik harus diberikan kebebasan untuk menemukan sendiri berbagai macam konsep serta materi ajar. Menurut teori belajar ini, salah satu alternatif yang dapat diterapkan untuk memperbaiki proses pembelajaran adalah dengan menerapkan model pembelajaran penemuan (Discovery Learning).

Model pembelajaran penemuan merupakan suatu model pembelajaran yang melibatkan peserta didik dalam proses pemecahan masalah untuk mengembangkan dan keterampilan yang dimilikinya. Model pembelajaran ini merupakan proses pembelajaran yang tidak memberikan keseluruhan materi ajar secara instan tanpa melibatkan peserta didik untuk mengorganisasi, mengembangkan pengetahuan dan keterampilannya sendiri untuk dapat memecahkan masalah yang masalahnya, sehingga dengan mengikuti setiap pembelajaran penemuan peserta didikdapat melatih kemampuan menemukan sendiri konsep ilmu pengetahuan dan pengetahuan baru dari yang awalnya peserta didik pasif menjadi aktif dalam kegiatan pembelajaran atau dari teacher oriented menjadi student oriented.

Model pembelajaran terjadi bila peserta didik tidak disajikan dengan pelajaran dalam bentuk akhir seperti pada umumnya, guru hanya menjelaskan materi pokok pembelajaran kemudian memberikan penugasan dalam bentuk isian singkat atau uraian. Namun, lebih dari itu peserta didik diharapkan dapat mengorganisasi sendiri, menemukan sendiri, menganalisis sendiri, dan kemudian membuat kesimpulan sendirisetelah melalui serangkain proses pembelajaran yang dirancang sedemikian rupa dan guru sebagai fasilitatornya. Prinsip belajar yang nampak jelas dari model pembelajaran penemuan (adalah materi atau bahan pelajaran yang akan disampaikan tidak disampaikan dalam bentuk final akan tetapi peserta didik didorong untuk dapat mencari informasi sendiri kemudian mengorganisasi atau membentuk (konstruktif) apa yang mereka ketahui dan mereka pahami dalam suatu bentuk akhir sesuai dengan pemahamannya 
sendiri. Guru dituntut untuk mampu memberikan penguatan atas apa yang telah ditemukan, diketahua, disimpulkan peserta didik menjadi pengetahuan baru yang ditemukan oleh peserta didik.

Model pembelajaran ini dilaksanakan melalui beberapa tahap mulai dari pemberian stimulasi, identifikasi masalah, mengumpulkan data, mengolah data, menganalisis data, pembuktian dan menarik kesimpulan. Sinambela (2017: 8) langkah-langkah pelaksanaan Discovery learning diawali dengan pemberian rangsangan(stimulation). Dalam tahapan ini peserta didik diberi suatu gambaran kondisi yang dapat menyebabkan mereka bingung dan merasa bertanya-tanya sehingga menimbulkan keinginan untuk mengamati lebih lanjut. Guru membimbing serta memberi pertanyaan atau arahan untuk membaca sebuah teks yang terkait dengan konsep yang akan ditemukan. Langkah selanjutnya, peserta didik dituntun untuk mengidentifikasi masalah (problem statement). Dalam hal ini, guru memberikan kesempatan kepada peserta didik untuk menemukan kejadian atau peristiwa dari masalah yang berkaitan dengaan konsep yang akan ditemukan, dan memilih salah satu masalah yang dapat dirumuskan dalam bentuk dugaan sementara (hipotesis). Setelah itu peserta didik dituntun untuk mengumpulkan data (data collection) yang akan dijadikan bahan untuk membuktikan dugaan sementara (hipotesis) yang telah ditentukan sebelumnya. Kegiatan ini dapat dilakukan dengan mengumpulkan informasi sebanyak-banyaknya dengan cara melakukan pengamatan, penyelidikan, percobaan, membaca sumber belajar, atau wawancara dengan nara sumber dilanjutkan dengan kegiatan pengolahan data (data processing). Dalam tahapan ini peserta didik mengolah informasi yang didapat sebelumnya dan mengaitkan dengan pengetahuan yang sudah dimiliki. Tahapan selanjutnya adalah pembuktian (verification). Dalam tahapan ini, peserta didik membuktikan benar tidaknya hasil temuan berdasarkan data dan informs yang telah ditemukan sebelumnya. Kegiatan pembuktian dapat dilakuan dengan cara kegiatan diskusi kelas, presentasi, atau menyatukan pendapat melalui bimbingan dan arahan guru. (Pembuktian) yaitu kegiatan untuk membuktikan benar atau tidaknya pernyataan yang sudah ada sebelumnya. Akhir dari tahapan Discovery Learning adalah menarik kesimpulan (generalization). Peserta didik dibimbing untuk 
dapat menarik kesimpulan berdasarkan hasil pengumpulan data atau informasi yang telah dianalisis dan dibuktikannya sendiri.

Menurut Yuliana (2018: 21), Discovery Learning dapat membantu peserta didik untuk memperbaiki keterampilan proses kognitif yang telah dimiliki oleh peserta didik sesuai dengan ritme dan kecepatannya sendiri dalam memahami suatu konsep, merasa mendapatkan penghargaan diri pada saat kegiatan berdiskusi, merasa senang atas capaian yang diperoleh setelah berhasil melakukan penelitian, dapat menghilangkan keraguraguan(skeptisme) karena mendapatkan pengetahuan yang pasti karena dibuktikan sendiri melalui serangkaian proses pembelajaran.

Dalam hal ini, Discovery Learningdapat dijadikan rujukan guru untuk membantu peserta didik untuk memperbaiki dan meningkatkan keterampilan dan proses kognitif, mengembangkan kemampuan menemukan sendiri konsep materi ajar. Pengetahuan yang diperoleh melalui model pembelajaran ini dianggap sangat ampuh secara personal karena menguatkan pengertian, ingatan dan transfer pengetahuan, serta dapat menimbulkan rasa senang pada peserta didik karena merasa mampu dan telah berhasil melakukan kegiatan penyelidikan, percobaan, dan wawancara. Dengan demikian, pada kesempatan berikutnya mereka akan mampu mengarahkan kegiatan belajarnya sendiri dengan melibatkan akal dan motivasinya sendiri.Selain itu, model pembelajaran ini dapat membantu peserta didik memperkuat konsep dirinya karena memperoleh kepercayaan bekerja sama dengan orang lain, aktif mengeluarkan gagasan-gagasan, memahami konsep dasar dan ide-ide, serta membantu mengembangkan ingatan yang dapat mendorong peserta didik berpikir dan bekerja atas dasar inisiatif sendiri sehingga mampu merumuskan hipotesis sendiri, memberikan keputusan yang bersifat intrinsik, dan memungkinkan peserta didik belajar dengan memanfaatkan berbagai jenis sumber belajar. Discovery Learning diasumsikan dapat membantu peserta didik melatih berbagai macam keterampilan seperti kemampuan berpikir kritis.

Kemampuan berpikir kritis merupakan proses kognitif seseorang yang perlu dilatihkan secara terus menerus, karena antara satu individu dengan individu lainnya berbeda kemampuannya. Menurut Hamzah 
(2014: 47) berpikir kritis merupakan proses kognitif, tindakan mental untuk memperoleh pengetahuan baru. Untuk mendapatkan pengetahuan tersebut harus melalui kegiatan berpikir yang sistematis untuk mengkaji benda-benda, gejala-gejala, dan peristiwa sehingga diperoleh kesimpulan sebagai suatu pengetahuan baru. Menurut Fisher (2009:3) berpikir kritis adalah orientasi dan evaluasi yang terampil dan aktif terhadap kegiatan observasi, komunikasi, informasi, dan argumentasi.Ditegaskan oleh Filsaime, (2008: 56) berpikir kritis merupakan sebuah cara berpikir disiplin yang digunakan seseorang untuk mengevaluasi validitas sesuatu pernyataanpenyataan, ide-ide, argumen, dan hasil penelitian. Lebih lanjut Filsaime (2008: 56), memandang berpikir kritis sebagai suatu proses kemampuan berpikir cerdas yang bersumber dari penerapan konsep, analisis, sintesis, dan evaluasi aktif dan kemampuan berpikir yang dihasilkan dari kegiatan observasi, pengalaman, refleksi, menganalisis sebuah informasi sehingga mampu berkomunikasi sebagai penekanan rasa percaya diri yang dimiliki.

Berpikir kritis merupakan suatu konsep yang diterima oleh peserta untuk mencapai suatu tujuan pembelajaran dengan melibatkan analisis terhadap permasalahan yang diterima dari proses pembelajaran. Peserta didik yang memiliki kemampuan berpikir kritis biasanya tampak dari ciri khas seperti mampu mengidentifikasi suatu masalah dari sekumpulan data dan informasi yang diterimanya. Dari sana dia mampu menganalisis, mengomunikasikan, serta mengevaluasi sehingga dapat menarik kesimpulan dari apa yang telah dilakukannya. Fisher (dalam Hadinata, 2008) menyatakan bahwa indikator berpikir kritis di antaranya mampu mengenal masalah, mencari cara-cara yang dipakai untuk menangani masalah, mampu mengumpulkan data dan menyusun informasi, mampu mengenali asumsiasumsi dan nilai-nilai yang tidak dinyatakan, memahami dan menggunakan bahasa secara tepat, jelas dan khas, mampu menganalisis data, mampu menilai fakta dan mengevaluasi pernyataan-pernyataan, mampu mengenal adanya hubungan yang logis antar masalah-masalah, mampu menarik kesimpulan, mampu menguji kesamaan-kesamaan dan kesimpulan-kesimpulan yang orang lain ambil, mampu menyusun kembali pola-pola keyakinan 
seseorang berdasarkan pengalaman yang lebih luas, dan mampu membuat penilaian yang tepat dalam kehidupan sehari-hari.

Berdasarkan pendapat para ahli tersebut di atas, dalam penelitian ini indikator kemampuan berpikir kritis dirumuskan meliputi: (1) mampu mengenali masalah; (2) mampu mengidentifikasi; (3) mampu mengumpulkan data atau informasi; (4) mampu berkomunikasi (5) mampu mengevaluasi; (6) mampu menganalisis data; (7) mampu menarik kesimpulan; dan (8) mampu mengemukakan pendapat.

Berdasarkan uraian tersebut diatas, dapat disimpulkan, jika peserta didik sudah memiliki beberapa kecenderungan keterampilan berpikir kritis seperti tersebut di atas, bisa dipastikan hasil belajarnya juga akan meningkat. Hasil belajar terkait dengan pengukuran, kemudian akan terjadi suatu penilaian dan menuju evaluasi baik menggunakan tes maupun nontes (Widoyoko, 2015: 23). Hasil belajar merupakan realisasi atau pemekaran dari kecakapan-kecakapan potensial atau kapasitas yang dimiliki seseorang (Sukmadinata, 2005: 25). Hasil belajar seseorang dapat dilihat dari perilakunya baik perilaku dalam bentuk pengetahuan, keterampilan berpikir maupun keterampilan motorik. Menurut Sagala (2005: 67), hasil belajar adalah kemampuan-kemampuan positif yang dimiliki peserta didik setelah menerima pengalaman belajarnya. Hasil tersebut dapat dijadikan bahan refleksi untuk menentukan berhasil tidaknya proses pembelajaran yang sudah direncanakan dan dilakukan oleh guru dan peserta didik. Dari hasil belajar yang diperoleh peserta didik, guru dapat mengambil kesimpulan apakah pembelajaran yang sudah direncanakan dan dilaksanakan berhasil membantu peserta didik dalam upaya pencapaian kompetensi dan indikator pembelajaran. Bukan itu saja, hasil capaian tersebut dapat dijadikan tolok ukur keberhasilan pendidikan yang diselenggarakan oleh satuan pendidikan. Berdasarkan latar belakang masalah yang telah dipaparkan di atas, rumusan masalah dalam penelitian ini adalah dengan menerapkan Discovery Learning, apakah kemampuan berpikir kritis dan hasil belajar peserta didik dapat meningkat. Sedangkan tujuan penelitian ini adalah meningkatkan kemampuan berpikir kritis dan hasil belajar peserta didik melalui penerapan Discovery Learningi. 


\section{B. Metode}

Penelitian yang digunakan untuk memecahkan masalah tersebut adalah Penelitian Tindakan Kelas (PTK). PTK adalah suatu penelitian yang menunjuk pada suatu kegiatan yang mencerminkan suatu objek dengan menggunakan cara atau aturan dan metodologi tertentu untuk memperoleh data atau informasi yang bermanfaat dalam meningkatkan mutu pendidikan. Penelitian Tindakan Kelas yang digunakan adalah model Kemmis dan Mc Taggart (Arikunto, 2007: 77) terdiri dari empat tahapan penelitian tindakan kelas yakni perencanaan (planning), pelaksanaan (action), pengamatan (observation), dan refleksi (reflecting).

Pada kegiatan perencanaan kegiatan yang dilakukan peneliti adalah membuat perangkat pembelajaran, lembar observasi, membuat tes hasil belajar, melakukan validasi, membuat LKPD, membuat bahan tayang. Tahap pelaksanaan berisi kegiatan pembelajaran dengan menerapkan model Discovery Learning, observasi berisi kegiatan pengamatan terhadap pelaksanaan tindakan dan pengamatan terhadap kemampuan berpikir kritis peserta didik, dan diakhiri dengan refleksi berisi kegiatan diskusi tentang hasil penelitian dan menganalisis kemampuan berpikir kritis dan hasil belajar peserta didik. Tujuannya untuk melihat sejauh mana pengaruh tindakan terhadap kemampuan berpikir kritis dan hasil belajar peserta didik. PTK ini dilakukan sebanyak dua siklus, masing-masing siklus terdiri tiga kali pertemuan.

Subyek dalam penelitian ini adalah guru dan seluruh peserta didik kelas VII.3 SMP Negeri 1 Tilamuta yang berjumlah 25 orang yang terdiri dari 11 orang pria dan 14 orang wanita. Penelitian ini dilaksanakan pada semester ganjil Tahun Ajaran 2018/2019. Teknik pengumpulan data yang digunakan meliputi: observasi dengan menggunakan lembar pengamatan terhadap ketercapaian keterlaksanaan pembelajaran dan kemampuan berpikir kritis; tes hasil belajar kompetensi pengetahuan untuk mengetahui keberhasilan tindakan yang dituangkan ke dalam skor perolehan hasil belajar. Instrumen penelitian yang digunakan adalah lembar pengamatan keterlaksanaan pembelajaran untuk mengamati aktivitas guru dalam proses pembelajaran sesuai dengan langkah-langkah Discovery Learning, 
lembar observasi untuk mengamati keterampilan berpikir kritis peserta didik, LKPD sebagai petunjuk peserta didik dalam melaksanakan kegiatan pembelajaran; lembar tes dalam dalam bentuk pilihan ganda untuk mengukur hasil belajar kompetensi pengetahuan. Teknik analisis data untuk mengetahui persentase keterlaksanaan pembelajaran dengan menggunakan rumus berikut.

$$
\text { Keterlaksanaan }=\frac{\text { Indikator yang terlaksana }}{\text { Jumlah seluruh indikator }} \times 100
$$

Teknik analisis data untuk mengetahui tingkat keterampilan berpikir kritis peserta didik dan hasil belajar kompetensi pengetahuan dengan menggunakan rumusberikut.

$$
\text { Nilai }=\frac{\text { Skor Perolehan }}{\text { Skor Maksimal }} \times 100
$$

Penetapan kriteria keberhasilan atau ketuntasan dengan menggunakan Penilaian Acuan Kriteria (PAK), dimana nilai ketuntasan kompetensi pengetahuan dan kemampuan berpikir kritis dituangkan dalam bentuk angka dan huruf. Nilai ketuntasan pengetahuan dan keterampilan berpikir kritis ditetapkan dengan skor 71. Secara klasikal ketuntasan belajar peserta didik dihitung dengan rumus:

$$
\text { Persentase } \frac{\text { Jumlah peserta didik dgn nilai } \geq 71}{\text { Jumlah Peserta didik }} \times 100
$$

Indikator keberhasilan pelaksanaan tindakan dalam penelitian ini adalah minimal 85\% tahap-tahap model pembelajaran Discovery Learning sudah dikuasai guru, atau pada kategori minimal Baik; Minimal 80\% peserta didik sudah menguasai indikator berpikir kritis atau sudah mencapai skor minimal 71 ; minimal $80 \%$ peserta didik memperoleh hasil belajar sesuai dengan KKM sekolah yakni 71. Penentuan ketuntasan hasil belajar didasarkan pada KKM yang berlaku di SMP Negeri 1 Tilamuta yaitu 71 secara individual dan 80 secara klasikal.

\section{Hasil dan Pembahasan}

Penelitian ini merupakan penelitian tindakan kelas yang tahapannya yang dikenal dengan istilah siklus. Penelitian ini dilakukan dalam dua siklus, masing-masing siklus sebanyak tiga kali pertemuan. Pelaksanaan pembelajaran tiap siklusnya mengacu pada perangkat pembelajaran yang telah disusun dan divalidasi pada tahap perencanaan. Tahapan dalam 
pembelajaran terdiri dari lima tahapan/sintaks model Discovery Learning yakni, meliputi stimulation (stimulasi/ pemberian rangsangan), problem statement (pertanyaan/ identifikasi masalah), data collection (pengumpulan data), data processing (pengolahan data), dan generalization (menarik kesimpulan).

Data hasil pengamatan keterlaksanaan pembelajaran Siklus I dan Siklus II yang meliputi kegiatan guru dalam menerapkan model pembelajaran penemuan (Discovery Learning). Data keterlaksanaan pembelajaran dapat dilihat pada Tabel 1 berikut.

\begin{tabular}{|c|c|c|c|}
\hline No & Siklus & Keterlaksanaan & Rerata \\
\hline 1 & I & $100 \%$ & $77,33 \%$ \\
\hline 2 & II & $100 \%$ & $92,00 \%$ \\
\hline
\end{tabular}

Tabel 1 tersebut di atas menunjukkan keterlaksanaan model Discovery Learning pada siklus I diperoleh data bahwa pembelajaran sudah dilaksanakan oleh guru secara keseluruhan. Namun, keseluruhan capaiannya baru 77,33\%. Setelah siklus II model Discovery Learning seluruhnya terlaksana dan hasil pengamatan sudah meningkat menjadi $92 \%$. Untuk mempermudah melihat perbandingan keterlaksanaan pembelajaran siklus I dan siklus II disajikandalam Grafik 1 sebagai berikut.

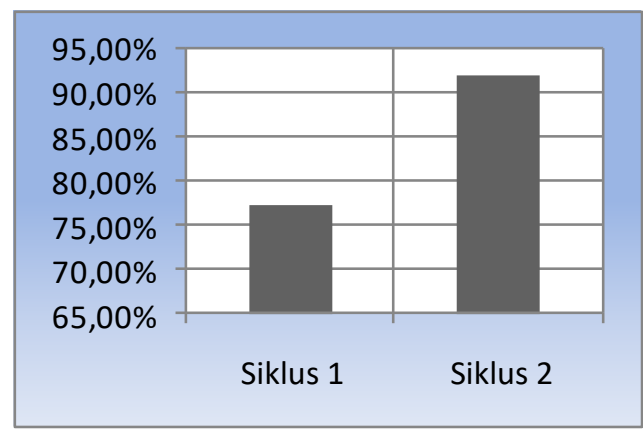

Gambar 1: Grafik Keterlaksanaan Pembelajaran

Grafik tersebut menunjukkan adanya peningkatan persentase keterlaksanaan pembelajaran dengan menerapkan model Discovery Learning dari siklus I ke siklus II. Hal ini menunjukkan bahwa guru sudah berusaha memperbaiki kekurangan serta kesalahan yang dilakukan pada siklus I. 
Guru lebih aktif membimbing, mengarahkan serta sabar dan teliti dalam menerapkan sintaks model Discovery Learning. Guru sudah menyadari bahwa dengan menerapkan model pembelajaran ini berarti harus lebih banyak memfasilitasi peserta didik agar dapat lebih aktif dan kreatif serta mampu mengambil peran dalam kegiatan pembelajaran. Dalam pembelajaran tradisional peserta didik hanya pasif, kurang berinisiatif, dan cenderung malas karena pembelajaran tidak merangsang keingintahuan peserta didik. Peserta didik belum terbiasadirangsang dengan sesuatu yang menarik perhatiannya, belum berani melakukan pengamatan secara mandiri, belum terbiasa melakukan identifikasi, menganalisis sebuah masalah dan mempresentasikan hasil pekerjaannya, serta belum berani mengemukakan pendapatnya sendiri di hadapan guru, teman-temannya dan belum mampu bertanya maupun menjawab pertanyaan baik dari guru maupun sesama teman. Penerapan model Discovery Lerning dapat meminimalisir itu semua sehingga apa yang menjadi tujuan pembelajaran dapat dengaan mudah tercapai.

Melalui model Discovery Learning, peserta didik terlihat lebih aktif melakukan pengamatan, mengumpulkan data yang diperlukan, aktif berdiskusi antar teman, adanya kegiatan tanya jawab, tidak kelihatan canggung lagi bekerja sama dalam kelompok dan peserta didik sudah mampu membuat karya dan menyajikannya dalam bentuk laporan sederhana dan berani melakukan presentasi di depan kelas. Guru dalam pembelajaran lebih terfokus pada kegiatan membimbing serta mengarahkan kegiatan peserta didik dalam merumuskan hasil pengamatan, mengidentifikasi, menganalisis, melakukan presentasi kelas, menarik kesimpulan serta sesekali dapat memberikan reward kepada individu atau kelompok yang berkinerja baik. Sehingga pembelajaran lebih berkualitas dan bermakna yang dapat membantu peserta didik mendapatkan pengalaman baru, dan menemukan sendiri konsep materi pembelajaran tanpa melalui kegiatan mencatat dan menghafal. Hal ini dapat dilihat dari meningkatnya aktifitas guru, meningkatnya kemampuan berpikir kritis dan hasil belajar peserta didik. Data keterampilan berpikir kritis peserta didik dapat di lihat pada Tabel 2 berikut. 
Tabel 2 Data Profil Kemampuan Berpikir Kritis Peserta Didik

\begin{tabular}{|c|c|c|c|c|c|c|c|c|c|}
\hline \multirow{3}{*}{ No } & \multirow{3}{*}{$\begin{array}{c}\text { Inisial } \\
\text { Peserta } \\
\text { Didik }\end{array}$} & \multicolumn{8}{|c|}{ Kemampuan Berpikir Kritis } \\
\hline & & \multicolumn{4}{|c|}{ Siklus I (Predikat) } & \multicolumn{4}{|c|}{ Siklus II (Predikat) } \\
\hline & & $\mathrm{A}$ & $\mathrm{B}$ & $\mathrm{C}$ & $\mathrm{D}$ & A & $\mathrm{B}$ & $\mathrm{C}$ & $\mathrm{D}$ \\
\hline 1 & $\mathrm{AD}$ & & & & $\sqrt{ }$ & & & $\sqrt{ }$ & \\
\hline 2 & ANL & & & & $\sqrt{ }$ & $\sqrt{ }$ & & & \\
\hline 3 & ANN & & & $\sqrt{ }$ & & $\sqrt{ }$ & & & \\
\hline 4 & ADD & & & & $\sqrt{ }$ & $\sqrt{ }$ & & & \\
\hline 5 & $\mathrm{AL}$ & & & & $\sqrt{ }$ & & $\sqrt{ }$ & & \\
\hline 6 & $\mathrm{AB}$ & & & $\sqrt{ }$ & & & $\sqrt{ }$ & & \\
\hline 7 & $\mathrm{AL}$ & & & $\sqrt{ }$ & & & & $\sqrt{ }$ & \\
\hline 8 & DAL & & & & $\sqrt{ }$ & & & $\sqrt{ }$ & \\
\hline 9 & EP & & & $\sqrt{ }$ & & & $\sqrt{ }$ & & \\
\hline 10 & FRL & & & & $\sqrt{ }$ & $\sqrt{ }$ & & & \\
\hline 11 & GOS & & $\sqrt{ }$ & & & & $\sqrt{ }$ & & \\
\hline 12 & HM & & $\sqrt{ }$ & & & & $\sqrt{ }$ & & \\
\hline 13 & IS & & & & $\sqrt{ }$ & & & & $\sqrt{ }$ \\
\hline 14 & KL & & & & $\sqrt{ }$ & & & $\sqrt{ }$ & \\
\hline 15 & MRD & & & & $\sqrt{ }$ & & & $\sqrt{ }$ & \\
\hline 16 & NTA & & & & $\sqrt{ }$ & & & & $\sqrt{ }$ \\
\hline 17 & NAT & & & & $\sqrt{ }$ & & & & $\sqrt{ }$ \\
\hline 18 & RL & & & $\sqrt{ }$ & & $\sqrt{ }$ & & & \\
\hline 19 & RS & & $\sqrt{ }$ & & & & & $\sqrt{ }$ & \\
\hline 20 & RM & & & $\sqrt{ }$ & & $\sqrt{ }$ & & & \\
\hline 21 & SR & & & $\sqrt{ }$ & & $\sqrt{ }$ & & & \\
\hline 22 & $\mathrm{SNH}$ & & $\sqrt{ }$ & & & & $\sqrt{ }$ & & \\
\hline 23 & ST & & & $\sqrt{ }$ & & & & $\sqrt{ }$ & \\
\hline 24 & $\mathrm{YH}$ & & $\sqrt{ }$ & & & & & $\sqrt{ }$ & \\
\hline 25 & ZK & & & $\sqrt{ }$ & & & $\sqrt{ }$ & & \\
\hline
\end{tabular}

Tabel 2 menunjukkan bahwa kemampuan berpikir kritis peserta didik secara umum mengalami peningkatan ke predikat yang lebih baik dari Siklus I ke Siklus II, walaupun ada yang tidak mengalami peningkatan. Pada Siklus I tidak ada peserta didik yang mendapatkan predikat sangat baik A), tetapi pada Siklus II ada 8 orang (32\%) yang mendapatkan predikat sangat baik (A). Peserta didik yang mendapat predikat cukup (D) pada Siklus I berjumlah 11 orang (12\%) berkurang jumlahnya pada Siklus II tinggal 3 orang (12\%) yang mendapatkan predikat cukup (D).

Untuk mempermudah melihat profil kemampuan berpikir kritis peserta didik, data tersebut dapat disajikan dalam bentuk grafik 2 berikut. 


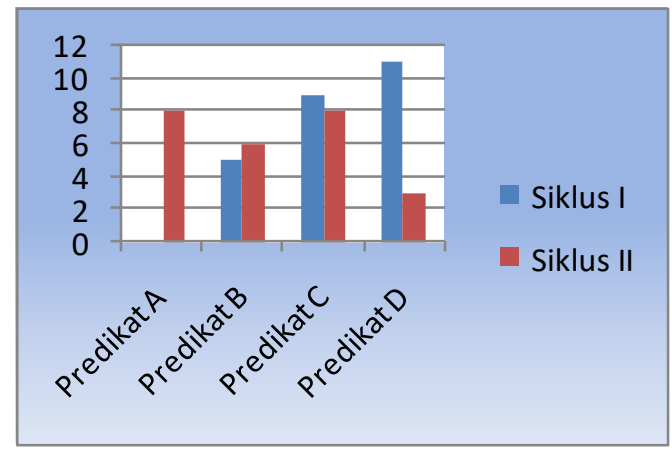

Grafik 2 Kemampuan Berpikir Kritis

Dari hasil analisis data tersebut dapat dijelaskan bahwa penerapan model Discovery Learning dapat meningkatkan kemampuan berpikir kritis peserta didik. Hal ini sesuai dengan pendapat Sapitri (2016: 32), yang menguraikan bahwa dengan menerapkan model Discovery Learning kemampuan berpikir kritis peserta didik dapat meningkat baik dalam indikator kemampuan mengambil keputusan, membandingkan dan memecahkan masalah. Dengan meningkatnya kemampuan berpikir kritis peserta didik, secara langsung berpengaruh terhadap peningkatan hasil belajar peserta didik.

Data peningkatan hasil belajar peserta didik dapat di lihat pada Tabel 3 berikut.

Tabel 3 Data Peningkatan Hasil Belajar Peserta Didik

\begin{tabular}{|c|c|c|c|c|c|c|c|c|c|}
\hline \multirow{3}{*}{ No } & \multirow{3}{*}{$\begin{array}{c}\text { Inisial } \\
\text { Pesert } \\
\text { a } \\
\text { Didik }\end{array}$} & \multicolumn{8}{|c|}{ Hasil Belajar } \\
\hline & & \multicolumn{4}{|c|}{$\begin{array}{c}\text { Siklus I } \\
\text { (Predikat) }\end{array}$} & \multicolumn{4}{|c|}{$\begin{array}{c}\text { Siklus II } \\
\text { (Predikat) }\end{array}$} \\
\hline & & $\mathrm{A}$ & $\mathrm{B}$ & $\mathrm{C}$ & $\mathrm{D}$ & A & $\mathrm{B}$ & $\mathrm{C}$ & $\mathrm{D}$ \\
\hline 1 & $\mathrm{AD}$ & & 86,67 & & & 93,33 & & & \\
\hline 2 & ANL & & 86,67 & & & & & 73,33 & \\
\hline 3 & ANN & & & 80,00 & & 93,33 & & & \\
\hline 4 & ADD & & 86,67 & & & 93,33 & & & \\
\hline 5 & $\mathrm{AL}$ & & & 80,00 & & & 86,67 & & \\
\hline 6 & $\mathrm{AB}$ & & & & 66,67 & 93,33 & & & \\
\hline 7 & $\mathrm{AL}$ & & & & 66,67 & 1 & 86,67 & & \\
\hline 8 & DAL & & & & 66,67 & 100 & & & \\
\hline 9 & $\mathrm{EP}$ & & & & 66,67 & 100 & & & \\
\hline 10 & FRL & & 86,67 & & & 100 & & & \\
\hline 11 & GOS & & & & 66,67 & 53,33 & & & \\
\hline 12 & $\mathrm{HM}$ & & & & 66,67 & & & & \\
\hline 13 & IS & & & & 66,67 & 93,33 & & & \\
\hline 14 & KL & & & 73,33 & & & & 73,33 & \\
\hline 15 & MRD & & & 73,33 & & & 86,67 & & \\
\hline 16 & NTA & & & & 60,00 & & & & 60,00 \\
\hline
\end{tabular}




\begin{tabular}{|l|c|l|l|c|c|c|c|c|c|}
\hline 17 & NAT & & & 73,33 & & & 86,67 & & \\
\hline 18 & RL & & & 73,33 & & & & 73,33 & \\
\hline 19 & RS & & & & 60,00 & 100 & & & \\
\hline 20 & RM & & & 80,00 & & & & 73,33 & \\
\hline 21 & SR & & 86,67 & & & & & & 60,00 \\
\hline 22 & SNH & & & 73,33 & & 93,33 & & & \\
\hline 23 & ST & & & 73,33 & & 100 & & & \\
\hline 24 & YH & & & 66,67 & & & & 66,67 \\
\hline 25 & ZK & & & 46,67 & & & 73,33 & \\
\hline
\end{tabular}

Tabel 3 menunjukkan bahwa baik Siklus I maupun Siklus II tidak ada peserta didik yang mendapatkan nilai nol, walaupun pada siklus I ada 11 orang $(44 \%)$ peserta didik yang memperoleh predikat $\mathrm{D}$ atau yang mendapatkan nilai (<71). Namun pada Siklus II meningkat dan tinggal 3 orang $(12 \%)$ peserta didik yang mendapatkan predikat $\mathrm{D}$ atau yang mendapatkan nilai $(<71)$. Pada Siklus I tidak ada seorang siswa yang mendapatkan nilai (91-100) atau predikat A, tetapi pada Siklus II meningkat menjadi 8 orang (32\%) yang mendapatkan nilai (91-100) atau predikat A.

Untuk mempermudah melihat profil kemampuan berpikir kritis peserta didik, data tersebut dapat disajikan dalam bentuk grafik 3 berikut.

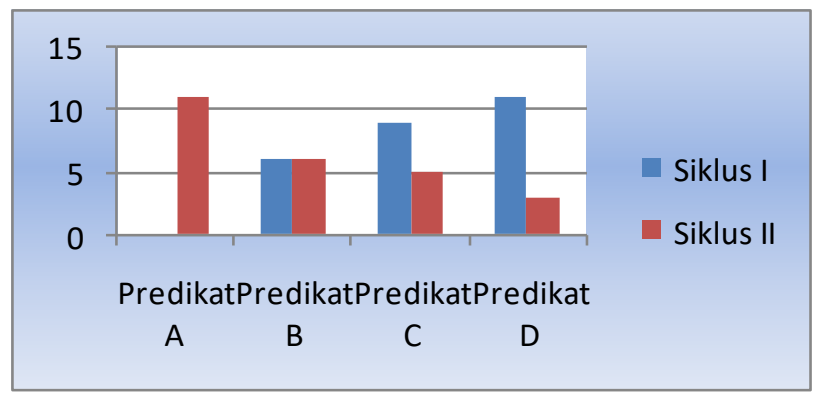

Grafik 3 Peningkatan Hasil Belajar Peserta Didik

Dari hasil analisis data dapat dijelaskan bahwa dengan mengimplementasikan model Discovery Learning hasil belajar peserta didik dapat meningkatkan. Hal ini sesuaidengan teori belajar Kontruktivisme yang menjelaskan bahwa agar siswa benar-benar memahami konsep dan menerapkan pengetahuan, mereka harus bekerja memecahkan masalah pembelajaran, menemukan sendiri segala sesuatu untuk dirinya, berusaha susah payah dengan ide-ide (Trianto, 2007: 57). 
Model pembelajaran ini mempermudah tugas guru dalam menyampaikan konsep tanpa harus dilakukan secara verbal dan peserta didik secara bertahap mulai terbiasa menemukan sendiri konsep materi ajar. Secara keseluruhan peserta didik dapat mencapai KKM yang telah ditentukan dan penguasaan peserta didik terhadap konsep pembelajaran sudah sesuai dengan indikator pembelajaran. Hal ini senada dengan hasil penelitian Sapitri (2016: 66), menjelaskan bahwa implementasi model Discovery Learning dapat meningkatkan keterampilan berpikir kritis peserta didik secara signifikan. Wulan (2020: 1477), juga menjelaskan bahwa model Disvovery Learning sangat efektif untuk meningkatkan keterampilan berpikir kritis peserta didik dan pemahaman konsep yang dibelajarkan oleh guru. Perubahan ini semakin hari semakin meningkat, dikarenakan dalam model Discovery Learning peserta didik dapat lebih aktif dan memiliki inisiatif dalam proses pembelajaran karena peserta didik merasa tertantang mengikuti proses pembelajaran mulai dari tahap identifikasi masalah sampai dengan tahap menarik kesimpulan.

Penerapan model Discovery Learning memberikan pengalaman langsung kepada peserta didik karena mereka dapat saling berinteraksi aktif dengan teman dalam kelompoknya maupun dengan kelompok lain, sehingga pembelajaran lebih menarik perhatian dan memberikan kesan mendalam bagi peserta didik. Seperti apa yang dijelaskan dalam teori belajar Vigotsky anak-anak dapat mengembangkan konsep-konsep lebih sistematis, logis dan rasional karena adanya interaksi sosial antara satu anak dengan anak yang lain melalui percakapan dengan sesorang. Dalam Discovery Learning, peserta didik dapat menemukan sendiri konsep-konsep pembelajaran melalui interaksi yang terjadi secara alami tanpa pemberian sekumpulan materi langsung dari guru. Melalui pembelajaran kooperatif seperti ini, guru lebih mudah membiasakan peserta didik dalam kegiatan mengamati, mengidentifikasi, mengumpulkan data, menganalisis hasil pengamatan, menarik kesimpulan dan mempresentasikan hasilnya didepan kelas. Peserta didik merasa percaya diri karena telah mampu menyelesaikan kegiatan pembelajaran dengan hasil sesuai dengan tujuan ataupun indikator pembelajaran yang telah ditetapkan oleh guru. Bahkan, jika dalam kegiatan 
pembelajaran dapat menghasilkan produk tertentu melalui kinerja ilmiah, mereka dengan bangga memperlihatkan hasilnya di depan kelas. Peserta didik merasa bangga karena dirinya mampu dan diakui kemampuannya melalui kegiatan penguatan yang diberikan oleh guru. Terlebih lagi jika pada akhir pembelajaran diberikan tes dan mereka berhasil mencapai KKM yang telah ditetapkan, peserta didik merasa senang memperlihatkan hasilnya baik kepada teman, guru maupun orang tua. Hal ini menunjukkan bahwa model Discovery Learning tidak hanya mampu meningkatkan kemampuan berpikir kritis saja, tetapi hasil belajar meningkat dan kemampuan bersosialisasi serta interaksi antar sesama peserta didik menunjukkan perkembangan yang baik.

Secara bertahap guru dapat mengembangkan kompetensi peserta didik seperti kemampuan mengenali masalah, mengidentifikasi, mengumpulkan data atau informasi, berkomunikasi, mengevaluasi, menganalisis data, menarik kesimpulan, dan melakukan presentasi di depan orang lain. Beberapa kemampuan tersebut merupakan indikator kemampuan berpikir kritis yang tidak bisa dilatihkan jika guru hanya menggunakan model pembelajaran konvensional. Banyak potensi akademik peserta didik yang tidak bisa berkembang secara maksimal jika guru masih bertahan dengan paradigma lama yang terus membatasi aktivitas, kreatifitas, dan prakarsa peserta didik yang sebenarnya sudah ada pada diri peserta didik. Padahal guru hanya membutuhkan sedikit kerepotan agar mampu membantu peserta didik dalam menemukan sendiri konsep apa yang sedang diajarkan, atau keterampilan apa yang akan dilatihkan. Model Discovery Learning sangat tepat jika diterapkan dikelas-kelas pembelajaran agar kualitas pembelajaran bermakna yang berpihak pada peserta didik serta mampu memberikan kesan mendalam bagi peserta didik dan bukan hanya mengutamakan kompetensi pengetahuan sebagai satu-satunya hasil belajar. Secara otomatis, jika kemampuan berpikir kritis peserta didik meningkat, hasil belajarnya juga dengan sendirinya akan meningkat pula. Jika kemampuan berpikir kritis dan hasil belajar peserta didik dapat ditingkatkan dengan model pembelajaran penemuan, maka untuk melakukan pembelajaran yang bermakna tersebut dibutuhkan kemauan dan kemampuan guru dan 
sedikit bergeser dari zona nyaman untuk terus berkreasi dan berinisiatif mewujudkan pembelajaran yang menyenangkan dan menantang bagi siswa.

\section{Penutup}

Model Discovery Learning), secara bertahap dapat meningkatkan kemampuan berpikir kritis peserta didik dan secara signifikan berpengaruh terhadap perolehan hasil belajar.

Ada baiknya guru mencoba menerapkan berbagai variasi pembelajaran lainnya untuk meningkatkan kemampuan berpikir kritis dan hasil belajar mereka. Banyak model pembelajaran dan media pembelajaran yang dapat dipilih oleh guru.

\section{Ucapan Terima Kasih}

Dalam penyusunan penelitian ini, penulis banyak menerima bimbingan, dorongan, saran dan motivasi dari berbagai pihak. Pada kesempatan ini penulis ingin menyampaikan rasa terima kasih yang sebesar-besarnya kepada Kepala Sekolah dan Guru SMP Negeri 1 Tilamuta.

\section{Daftar Referensi}

Abdullah, A. A \& Richardo, R. . (2017). Menumbuhkan Kemampuan Berpikir Kritis Siswa dalam Memilih Makanan Sehat dengan Pembelajaran Literasi.Jurnal Gantang, 89-97.

Akbar, S., \& Hasby, H. (2019). The Profile of Student Analytical Skills through Hypothetical Learning Trajectory on Colligative Properties Lesson. Jurnal Ilmiah Peuradeun, 7(3), 455-468. doi:10.26811/peuradeun.v7i3.307

Arikunto, S. (2007). Penelitian Tindakan Kelas. Jakarta: Bumi Aksara.

Filsaime, D. K. (2008). Menguak Rahasia Berpikir Kritis dan Kreatif. Jakarta: Prestasi Pustakarya.

Fisher, A. (2009). Berpikir Kritis. Jakarta: Erlangga.

Hamzah, A. (2014). Perencanaan dan Strategi Pembelajaran Matematika. Jakarta: Rajawali Press.

Kadir, A. (2013). Konsep Pembelajaran Kontekstual di Sekolah. Jakarta: Dinamika Ilmu. 
Muzaffar, A., Irfan, A., \& Tabrani ZA. (2020). Kemampuan Pedagogical Content Knowledge Alumni Pendidikan Bahasa Arab Fakultas Tarbiyah dan Keguruan UIN Ar-Raniry Banda Aceh. Jurnal Ilmiah Didaktika: Media Ilmiah Pendidikan dan Pengajaran, 21(1), 41-60. doi: http://dx.doi.org/10.22373/jid.v21i1.7129

Nur, M. (2011). Model Pembelajaran Berbasis Masalah. Surabaya: UNESA.

Sagala, S. (2005). Konsep dan Makna Pembelajaran untuk membantu Memecahkan Problematika Belajar dan Mengajar. Bandung: Alfabeta.

Sapitri, E. U, Kurniawan, Y \& Sulistri, E. Efektivitas Discovery Learning untuk Meningkatkan Kemampuan Berpikir Kritis dan Penguasaan Konsep Asam Basa.Jurnal Ilmu Pendidikan Fisika. 1 (2). 64-66. p-ISSN: 2477-5959eISSN: $2477-8451$

Sinambela, P. N. (2017). Kurikulum 2013 dan Implementasinya dalam Pembelajaran. Jakarta: Generasi Kampus.

Sukmadinata. (2005). Landasan Psikologi Proses Pendidikan. Bandung: Rosdakarya.

Tabrani ZA. (2012). Future Life of Islamic Education in Indonesia. International Journal of Democracy, 18(2), 271-284

Trianto. (2007). Model-model Pembelajaran Inovatif Berorientasi Kontruktivisme. Jakarta: Prestasi Pustaka.

Walidin, W., Idris, S., \& Tabrani ZA. (2015). Metodologi Penelitian Kualitatif $\mathcal{E}$ Grounded Theory. Banda Aceh: FTK Ar-Raniry Press.

Widiantoro, S. (2020). Pengembangan Model Pembelajaran Ecoprint untuk Meningkatakan Keterampilan Abad 21 di Sekolah Dasar. Jurnal Didaktika Pendidikan Dasar, 4(3), 759-778. https://doi.org/10.26811/didaktika.v4i3.142

Widoyoko. (2015). Evaluasi Program Pembelajaran. Yogyakarta: Pustaka Pelajar.

Wulan, F \& Ahmad, S. (2020). Model Discovery Learning Sebagai Upaya Meningkatkan Kemampuan Berpikir Kritis Siswa SD. Jurnal Pendidikan Tambusai, 4(2), 1469-1479. https://doi.org/10.31004/jptam.v4i2.612

Yuliana, N. (2018). Penggunaan Model Pembelajaran Discovery Learning dalam Peningkatan Hasil Belajar Siswa.Jurnal Ilmiah Pendidikan dan Pembelajaran, 21-28. 